\title{
WINDS OF CHANGE: SOME RECENT DEVELOPMENTS IN THE LAW OF EVIDENCE
}

D. C. MCDONALD*

\section{REFORM OF THE HEARSAY RULE}

About twenty-five years ago in Canada, there was a great deal of published commentary on the state of the law of hearsay. It was inspired by what was the then recently enacted Evidence Act $(1938)^{1}$ of England, which permits the admission into evidence of much documentary hearsay otherwise inadmissible at common law. In particular, documentary hearsay was made admissible under that statute even without calling the maker of the document as a witness when the latter is "dead, or unfit by reason of his bodily or mental condition to attend as a witness, or if he is beyond the seas and it is not reasonably practicable to secure his attendance, or if all reasonable efforts to find him have been made without success."

Viscount Maugham, author of the Act, was understandably proud of his accomplishment. He defended the limitation of the scope of the Act to civil proceedings on the ground that to have applied it to criminal proceedings would have invited opposition from ultra-conservative lawyers. He justified the limitation of the Act to documents on the basis of an expression of faith that the rule, so far as regards verbal (i.e. oral) hearsay, "is on the whole a most valuable one." $\mathrm{Mr}$. S. J. Helman, K.C., criticized the Act's restriction to documentary hearsay; and pointed out that in Scotland "the general rule has been that an oral statement by a deceased person is admissible in evidence, and no inconvenience has followed from the adoption of this practice." 3 He also touched on the history of reform in the United States, especially that in Massachusetts where a statute in 1898 provided that "No declaration of a deceased person shall be excluded as evidence on the ground of its being hearsay if it appears to the satisfaction of the Judge to have been made in good faith before the beginning of the suit and upon the personal knowledge of the declarant." After forty years of existence, the Massachusetts reform had gained the general approval of the Massachusetts bar." C. A. Wright criticised the Evidence Act of 1938 as "another niggling exception" to the hearsay rule, and "a piece-meal, nibbling approach" to the subject. He urged much more sweeping reform of the entire law of evidence, even apparently amounting to destruction of the exclusionary rules altogether and leaving admissibility to the discretion of the trial judge. ${ }^{5}$

In Canada the provisions of the Evidence Act of 1938 were included in the Uniform Evidence Act prepared by the Commissioners on Uni-

- David C. McDonald. B.A. (Alta.), M.A. (Oxon.), B.C.L. (Oxon.), of McCuaig, McCuais, Desrochers, Beckingham and McDonald, Edmonton, Alberta; Sessional Instructor. Faculty of Law, University of Alberta.

1 (Imp.) 1 \& 2 Geo. VI, c. 28.

Maugham Observations on the Law of Evidence (1939), 17 Can. B. Rev, 469,475

3 Helman, The Reform of the Law of Hearsay (1939), 17 Can. B. Rev. 302, 304.

4 Ibid, at 307 . See also Cowen \& Carter, Essays on the Law of Evidence 10 (1956). The precise wording of the Massachusetts statute, as quoted. is given by Maugham, ante, n. 2 , at 482.

s Wright, The Law of Evidence: Present and Future (1942), 20 Can. B. Rev. 714. 
formity of Legislation. ${ }^{B}$ However, the Uniform Act has been adopted only by the Northwest Territories. ${ }^{7}$ Independently of the Uniform Act, the English Act has been adopted by Manitoba. ${ }^{8}$

It may be said that, since the passage of the Evidence Act in 1938, and the discussion emanating from this reform, the winds of change have lain relatively quiet in the law of hearsay evidence in England and Canada. Perhaps the only developments in the nature of change worth noting have been the following:

1. The Judicial Committee of the Privy Council, in Teper v. The Queen, ${ }^{9}$ recognised that the doctrine of res gesta causes the admission of hearsay evidence. Although it seemed clear that statements admitted as part of the res gesta had at times been used as evidence of the truth of the matter asserted and were therefore hearsay, the orthodox view had been that the doctrine properly caused statements to be admitted only as original evidence. ${ }^{10}$ However, in Teper's case Lord Normand said:

The rule against the admission of hearsay evidence is fundamental. It is not the best evidence and it is not delivered on oath. The truthfulness and accuracy of the person whose words are spoken to by another witness cannot be tested by cross-examination, and the light which his demeanour would throw on his testimony is lost. Nevertheless, the rule admits of certain carefully safeguarded and limited exceptions, one of which is that words may be proved when they form part of the res gesta. ${ }^{11}$

This passage was quoted with approval by Smith, C.J.A., delivering the judgment of the Appellate Division of the Supreme Court of Alberta in $R$. v. Workman." Smith, C.J.A., also quoted a passage from Cross on Evidence, in which the author contended that the doctrine of res gesta constituted an exception to the hearsay rule. There is, therefore, ample and persuasive recent judicial authority for this proposition, the significance of which, other than from the standpoint of definition, is that it focusses attention upon the hearsay rule itself.

2. One consequence of the hearsay rule is that much relevant evidence is prevented from being used in the ascertainment of truth. From time to time, unjust results of the exclusionary rule have been avoided by resort to the amorphous res gesta doctrine. Some writers feel that this is an inadequate means of escaping from the rigours of the hearsay rule, and that any exceptions to the hearsay rule should be developed more rationally. ${ }^{13}$ On the other hand, the idea behind the doctrine of res gesta has been described as "an idea of great amplitude, and one fraught with tremendous possibilities." 14 This view was accepted in England by the

G Ss. 52-53. The Uniform Act is found in The Proceedings of the Canadian Bar Association, 1945, pp. 271-300.

T Revised Ordinances N.W.T. 1956 , c. 31, ss. $52-53$

8 Now R.S.M. 1964, c. 75, ss. 52-54. The Manitoba Act states in s. 54 (1) the following conditions for excusing the attendance of the maker of the statement: "If he is dead unfit by reason of bodily or mental condition to attend as a witness, or if he is without unfit by reason of bodily or mental condition to attend as a witness, or if he is without reasonable efforts to find him have been made without success."

D |1952| A.C. 480 ; $[1952] 2$ All E.R. 447 (P.C.).

10 R. v. Christie, [1914] A.C. 545, 553, per Lord Atkinson; R. v. Wilkinson (1934), 8 M.P.R. 562 (N.S.C.A.); R. v. Leland, [1951] O.R. 12 (Ont. C.A.).

11 [1952| A.C. 480, 486; $|1952| 2$ All. E.R. 447,449.

12 1963] 1 C.C.C. 297 aff'd on other grounds $|1963|$ S.C.R. 266. The decision is criticised by Fuller in (1964), 3 Alta. L. Rev. 299 on the ground that the statement of the intention, which was admitted as part of the res gesta to prove that the deceased went to a particular place, was really irrelevant to that fact and suffered from the same dangers as the similar evidence in the famous case of Mutual Life Insurance Company v. Hillmon (1892), 145 U.S. 285.

13 E.8., Murray, Evidence: A Fresh Approach (1959), 37 Can. B. Rev. 576, 590: "a wretched

14 Gooderson, Res Gesta in Criminal Cases, [1956] Camb. L.J. 199. 
Report of the Committee on Supreme Court Practice and Procedure (The Evershed Committee) in 1952, which treated evidence admitted under the res gesta doctrine as hearsay and urged readier use of the doctrine. The Committee expressed

the hope that the judges, if possible by concerted action, will bring their influence to bear on the side of the fullest use of the facilities given [by the Evidence Act of 1938, and also], in appropriate circumstances, by a liberal interpretation of the rule of evidence known as Res Gesta. It has been represented to us that, particularly in personal injury actions, the admission, as evidence which might otherwise be barred under the hearsay rule, of statements overheard on the part of third parties at or about the time of events giving rise to the cause of action would greatly assist in the ascertainment of the truth. The formulation of any revision of the Res Gesta rule presents the greatest difficulties and not the least because the admission of such evidence is largely a matter of the discretion of the judge to be exercised in accordance with principles laid down in decided cases. We therefore think that the judges themselves could greatly help towards such a relaxation of the strict application of this rule as would assist in the determination of the matter in issue. We add that if such a practice on the part of judges is to achieve its purpose in saving costs, it is essential that their view should become generally known among those responsible for the conduct of this kind of action.1:

Professor Murray describes this as a "choice example of English muddling through," and argues that the doctrine ought to be abandoned in favour of specific well-defined exceptions to the hearsay rule. ${ }^{1 n}$ Nevertheless, the Report does illustrate that, short of statutory reform, the res gesta doctrine is capable of being used to mitigate the effects of the hearsay rule.

3. In 1964, the decision of the House of Lords in Myers v. Director of Public Prosecutions, ${ }^{17}$ while unsurprising and perhaps unimportant in its results, was significant for its stinging condemnation of the absurd results which can be produced by the hearsay rule or at least by badly formulated exceptions to the hearsay rule. To prove theft of automobiles, in that case, the Crown relied partly on evidence which was held to be inadmissible as hearsay and fell within neither the exception for declarations in the course of duty nor the exception for public documents. Lord Reid described the law regarding hearsay evidence as "absurdly technical"; and said, of the rule, than in many cases there is "no justification either in principle or logic for carrying the exception just so far and no farther. One might hazard a guess that when the rule proved highly inconvenient in a particular kind of case it was relaxed just sufficiently far to meet that case, and without regard to any question of principle." Lord Pearce quoted Wigmore, who

was of opinion that the rule has been over-enforced and abused and concluded that 'the problem for the coming generation is to preserve the fundamental value of the rule, while allowing the amplest exceptions to it and abstaining from petty meticulous exceptions. ${ }^{1 \mathrm{~s}}$

The accused was charged with conspiracy to receive stolen cars. His system was to buy wrecked cars together with their log books (issued by the local authorities on registration).

15 Cmd. 8878,1953, p. 88 . Insofar as the passage quoted seems to suggest a more liberal use of res gesta, particularly in one type of action. it should be borne in mind that criminal proceedings were beyond the purview of the committee.

16 (1959), 37 Can. B. Rev. 576, 590.

17 [1964] 3 W.L.R. 145; [1964] 2 All E.R. 881.

18 Wigmore on Evidence Vol. 5, p. 27 (3rd ed.), also quoted in Cross on Evidence 383, (2nd ed.). Quoted by Lord Pearce in [1964] 3 W.L.R. 145, 170; [1964] 2 All E.R. 881, 895-96. 
Having brought a wrecked car he then stole a car as nearly as possible identical with the wrecked car and proceeded to disguise the stolen car so that it corresponded in every respect with the particulars of the wrecked car noted in its log book. He could then, as the thought, safely sell the disguised stolen car together with the genuine log book of the wrecked car.

The log book contains a chassis number and an engine number, and these had therefore to be transferred, together with the wrecked car's number plates, from it to the stolen car. As the chassis number and engine number appear on small plates which can be detached from the chassis or engine it was not difficult to substitute the genuine chassis and number plates taken from the wrecked car for those on the stolen car."1"

Evidence of unquestionable admissibility, identifying the stolen cars, was given in some eighteen instances, usually by the owners of the cars who indentified dents, scratches, or other features. In addition, there was evidence that licence plates and parts from eight of the stolen cars were found in garage premises occupied by Myers. All members of the House held that this evidence alone was overwhelming, so that the conviction should stand whatever view be taken of the evidence objected to by the appellant. The evidence objected to was given in relation to a few cars by two employees of the Austin Motor Car Company Ltd., manufacturer of the cars, who produced microfilm records of the cars' cylinder block numbers, which were indelibly stamped on the engines. As each car was being assembled, it was the duty of a workman to copy on a card the chassis, engine, and cylinder block numbers. These cards were photographed on microfilms and then destroyed. This evidence, as far as the cylinder block numbers were concerned, was, in Lord Reid's words (and all members of the House clearly were of the same view), "very cogent" evidence which "proved conclusively that the disguised car was the stolen car and not the wrecked car rebuilt." Yet it was held inadmissible. ${ }^{20}$ The following is a brief summary of the principal reasons advanced either by the Court of Criminal Appeal or by Crown Counsel before the House of Lords in support of admissibility, and the answers given by their Lordships:

(a) Such evidence was in practice admitted, at least at the Central Criminal Court (the Old Bailey). An instance of such practice which reached the law reports was Reg. v. Rice, where the conviction in that Court was upheld in the Court of Criminal Appeal."1 In that case, there was evidence of a kind which the Court of Criminal Appeal and Lord Pearce considered similar to the evidence in question in Myers. An air ticket marked in the name of Rice was held to be admissible as tending to prove that Rice had travelled by air from London to Manchester on or about a particular date. Winn, J., delivering the judgment of the Court of Criminal Appeal in Rice, had insisted that the ticket could not be regarded as hearsay, but his reasoning is not convincing. Widgery, J., delivering the judgment of the Court of Criminal Appeal in Myers, followed Rice; and said of the evidence before him that "the admission of such evidence does not infringe the hearsay rule because its probative value does not depend upon the credit of an unidentified person but rather on the circumstances in which the record is maintained and the inherent probability that it will be correct rather than incorrect." Again,

10 Per Lord Reid, [1964] 3 W.L.R. 145, 153; [1964] 2 All E.R. 881, 883.

20 By Lords Reid, Morris of Borth-y-Gest, and Hodson. Lords Pearce and Donovan dissented.

21 [1963] 1 Q.B. 857; [1963] 2 W.L.R. 585; [1963] All E.R. 832 (C.C.A.). 
this distinction fails to prove the point, because, whatever the reason for trusting the accuracy of the information on the card, surely the card is an assertion by a person being tendered to prove the truth of the matter asserted on the card, namely, that a certain car had a certain cylinder block number. ${ }^{22}$ Likewise, the analysis by Lord Pearce of the evidence in Rice and Myers as non-hearsay and merely "confirmatory" and "one of the circumstances which the jury might consider" fails to get to the root of the matter. But this could lead to a fuller discussion of this borderland of hearsay than space permits; and, since review of the very definition of the hearsay rule is not of pressing practical importance, it is not proposed to discuss the matter further at this time. Suffice it to say for present purposes that the majority of the House of Lords ignored Reg. v. Rice altogether, ${ }^{23}$ held the evidence to be hearsay, and considered that whatever the practice may have been in the Central Criminal Court, it could not be justified in principle.

(b) The Court of Criminal Appeal held that, although the records might not be evidence standing by themselves, they could be used to corroborate the evidence of other witnesses. Lord Reid retorted that "unless the jury were entitled to regard them as probably true records they afforded no corroboration at all. If the jury were entitled so to regard them, I can see no reason why they should only become admissible evidence after some witnesses have identified the cars for different reasons." 25 And Lord Morris of Borth-y-Gest said: "That which is not evidence is not to be made evidence by saying that if it were evidence it would confirm other evidence.": $: 0$ In other words, corroborative evidence must be capable of standing by itself.

(c) The Crown argued that, although the general rule may be that private records are not admissible to prove the truth of entries in them, the trial judge has a discretion to admit a record in a particular case if satisfied that it is trustworthy and that justice requires its admission. Lords Reid and Morris rejected this proposition; there is no inclusionary discretion which allows hearsay evidence to be heard, however cogent and credible it may be.

(d) It was submitted by the Crown "that documents of a private character should be admissible, if some independent evidence establishes that the maker of them cannot be identified or called and if it is proved that they were made contemporanously and in the course of duty and if it is proved that the documents are of such a nature that they are probably accurate."27 However, the majority of the House held that the decision of the House in Sturla v. Freccia ${ }^{23}$ bound them to hold that no such exception to the hearsay rule exists. The House also held that to create such an exception at this time would be to legislate. The exception which had been recognised in Sturla v. Freccia was for the contents of

22 As Lord Reld pointed out in [1964] 3 W.L.R. 145, 157: [1964] 2 All E.R. 881, 886.

23 Apparently, in argument before the House of Lords Crown counsel admitted that the records were hearsay: see Lord Reid in [1964] 3 W.L.R. 145, 156; [1964] 2 All E.R. $881,886$.

24 In (1964), 27 M.L.R., 606, 608, J. A. Andrews argues that the evidence has value, quite apart from the truth of the record, because of the enormity of the coincidence between apart from the truth of the record, because of the enormity of the coincidence between
the owner's testimony, the numbers in his log book, the cylinder block number, and the manufacturer's record.

$25[1964] 3$ W.L.R. 145, 157; [1964] 2 All E.R. 881, 886.

26 Id. at 161 and 889 respectively.

27 From the judgment of Lord Morris of Borth-y-Gest, ibid., at 162 and 889 respectively.

28 (1880), 5 App. Cas. 623, [1874-80] All E.R. Rep. 657. 
public documents only, and "it is quite clear that a record is not a public record within the scope of the rule unless it is open to inspection by at least a section of the public." 20

(e) Moreover, the records were not admissible as declarations made in the course of duty, because it could not be proved that the workmen who filled out the cards were dead. Yet, the same guarantees of trustworthiness that exist in relation to declarations made in the course of duty are present, as Lord Morris of Borth-y-Gest pointed out:

It has long been a part of our law that if a person in the regular course of his duty makes a contemporaneous record (which he could have no interest to make falsely) of some business matter which it was his duty to transact and if such person dies evidence of the record may be given to prove the performance of the transaction. The considerations that there was an obligation to perform the duty faithfully and that in matters of business routine, where no personal interest arises, accuracy can as a rule be expected, have been thought to give some reasonable guarantee of credibility. It can very powerfully be argued that the law might be changed so as to make admissible certain records made by persons who cannot be identified and who may or may not be alive .... All this may suggest that some modification of the law could without dangerous consequences and with advantage be made. The existing exception to the hearsay rule which admits evidence of declarations in the course of duty is, however, subject to the firmly established condition that the death of the declarant must be shown. It would be a positive alteration of the law to say that the condition need no longer be satisfied. ${ }^{30}$

The irony of admitting such private records only when the declarant is dead is illustrated vividly in Lord Pearce's dissenting judgment when he points out that, if the workmen who made the entries on the cards could be found and put on the stand, the cards or the films could have been used to "refresh their memories" or could have been produced by the workmen as records made by them. In either case putting them on oath and subjecting them to cross-examination would not have the least likelihood of exposing mistake. ${ }^{32}$

In England in civil cases, the Evidence Act of 1938 has substantially effected reform where evidence is available such as that in Myers; but in most Canadian provinces such evidence will continue to be excluded in both criminal and civil cases. In all of Canada, apart from the statutory provisions in Manitoba and the Northwest Territories already noted, there are just two decisions, both in Alberta, which would permit evidence of this kind. In J. H. Ashdown Hardware Company Limited v. Singer, ${ }^{32}$ an action for the price of goods sold and delivered, the defendant denied delivery. Giving the judgment of the Appellate Division of the Supreme Court of Alberta, Clinton J. Ford, J.A., said:

If the plaintiff relied on its ledger accounts of its business transactions with the

firm, without more, it could not succeed: Lischinsky v. Auld [1932] 3 W.W.R. 691 .

But we have in this case the evidence of the credit manager of the plaintiff, who had charge of and supervision of accounts with his customers. He was familiar with the system and method adopted by the company in the ordering and supplying, pursuant to any order, of goods and merchandise; the invoicing of such goods with the prices thereof on the order being filled; and the posting and entry in the ledger of the account with the customer. This was explained in his evidence, as well as the fact that monthly accounts were sent, based, of course, on the ledger, to the firm from time to time, without objection being received.

29 Per Lord Reid, [1964] 3 W.L.R. 145, 158; [1964] 2 All E.R. 881,887.

30 Id. at 161 and 889 respectively.

31 [1964] 3 W.L.R. 145, 168-69; [1964] 2 All E.R. 881, 895.

32 (1951), 3 W.W.R. (N.S.) 145, [1952] 1 D.L.R. 33 aff'd. [1953] 1 S.C.R. 252, [1953] 2 D.L.R.' 625 . 
It is true that there was no direct proof of actual delivery to or receipt by the firm of the goods in question, nor evidence by any clerk or servant of the plaintiff who personally sent out the goods, in fulfilment of any specific order; but, in my opinion, proof in this way cannot be reasonably required in present-day business in a large commercial concern where clerks and servants are changed from time to time, whose evidence may be difficult and often impossible to obtain, and who, even if brought before the Court, would have forgotten most of the particular transactions. ${ }^{33}$

His Lordship found support for this view in the decision of the same Court in Omand v. Alta. Milling Co. ${ }^{34}$

Where Beck, J.A., refers to proof of a carefully devised and a carefully conducted system, although in that case it was a governmental system of inspection followed by the making of records, as leading to a high probability of the correctness of the ultimate results and, the system having been proved by the supervisor, who verified the copies or duplicates of the reports used in the pursuance of the system, the contents of the reports were proved and held to be prima facie correct.3:

Clarke, J.A., concurred with Beck, J.A.; and Stuart, J.A., citing Wigmore, expressly justified the admission of the records under an exception to the hearsay rule on the grounds of (1) necessity arising out of the absurdity of saying that if the inspectors who made the records were called as witnesses their memories would be refreshed, and (2) the existence of a circumstantial guarantee of trustworthiness arising from complete disinterestedness, a duty to test, and a duty to record the test at the time.

However, the door thus opened, leading to admissibility of business entries in generally the same circumstances as provided for in the American Uniform Rules (to which reference will be made shortly), has not been entered by courts in any subsequent cases. The writer has had the personal experience of observing a trial judge refuse to apply these cases to hospital records made by internes and nurses..$^{36}$ During the trial of an issue as to testamentary capacity in 1963 in the Supreme Court of of Alberta, it was proposed on behalf of the party alleging incapacity to tender evidence of hospital charts recording nurses' and internes' comments on the deceased's behaviour at various times when she was hospitalized. The nurses had long since ceased employment at the hospital; some could be located in other parts of Alberta or in other provinces, and some could not be found. In reliance on Ashdown v. Singer, it was argued that at least some of this evidence was admissible, but the trial judge would not admit the evidence. No doubt other practitioners could give many examples of instances of the rejection of oral or written hearsay of considerable probative value by disinterested persons who had personal knowledge whereof they spoke and who were insane or could not be located. Such decisions usually are made by trial

33 (1951), 3 W.W.R. (N.S.) 145, 148-149; [1952] 1 D.L.R. 33, 35.

34 [1922]' 3 W.W.R. 412 , 18 Alta. L.R. 383. See also R. v. C.P.R., [1912] 2 W.W.R. 637 (a clivil case) cited by Beck, J.A., In Omand's case, where, however, the evidence does not appear to have been hearsay as the employee's conduct was not assertive. But neither Beck, J.A., nor Stuart, J.A. referred to more orthodox cases in which hearsay records of large companies were held not to be admissible in the absence of evidence that the employees making the records were dead: e.g., National Fire Insurance Company v. Rogers, [1924] 2 W.W.R. 186; [1924] 2 D.L.R. 402 (Sask. C.A.), (a case similar to Myers v. D.P.P. on its facts, a decision described by Wigmore as "a banner one for predantry in this field"); Lischinsky v. Auld, [1932] 3 W.W.R. 691 (Sask. C.A.), Nor-Wes Bldg. in this field"); Lischinsky v. Auld, [1932] 3 W.W.R. 691 (Sask. C.A.)

35 (1951) 3 W.W.R. (N.S.) 145, 149; [1952] i D.L.R. 33, 36. In the Omand case, [1922] 3 W.W.R. 412, 420, Beck, J.A., did not expressiy recognise that he was approving an exception to the hearsay rule.

36 Similar rulings in cases involving hospital records caused some American states to enact specific remedial legislation: Wigmore on Evidence, vol. 5, s. 1519. 
judges orally during the course of a trial, are seldom if ever reported, and are rarely if ever a ground of appeal. Lord Maugham gave several examples from his own practice of cases in which reports of engineers now ill or abroad, written reports by deceased surveyors, and old plans and photographs were inadmissible at common law but admissible in civil cases under the Evidence Act of 1938. ${ }^{37}$

The kind of evidence tendered in Myers v. D.P.P. and Ashdown v. Singer would be admissible in those American jurisdictions which have adopted statutory reforms such as Rule 63 (13) of the Uniform Rules of Evidence, ${ }^{38}$ stating an exception to the hearsay rule as follows:

Business Entries and the Like. Writings offered as memoranda or records of acts, conditions or events to prove the facts stated therein, if the judge finds that they were made in the regular course of a business at or about the time of the act, condition or event recorded, and that the sources of information from which made and the method and circumstances of their preparation were such as to indicate their trustworthiness.

It will be observed that this wording is not limited to declarations by persons having personal knowledge, although no doubt that would be the usual case in which a judge would be satisfied as to the trustworthiness of the document. It will also be noted that the exception is limited to documentary hearsay, like the Evidence Act of 1938. However, there is no limitation to records made by persons deceased or even insane, ill, or whose attendance is impossible to procure, as is found in the Evidence Act of 1938.

Reform along the lines of either the Evidence Act of 1938 or the Business Entries provision in the Uniform Rules would obviate the potential of injustice in most cases of the kind which have been discussed. As Lord Pearce observed in Myers, an exception permitting admission of the evidence in that case would be justified by necessity and a circumstantial guarantee of trustworthiness:

With the necessity created by death the courts were familiar and they evolved exceptions which dealt reasonably adequately with that phenomenon. With the necessity created by insanity Lord Eldon and Lord Cottenham had dealt and I cannot find that they have been over-ruled. The necessity created by mass production and modern business they could not then foresee. They did not provide for the anonymity of modern industrial records and the difficulty of tracing those who made them. The individuality of persons in a large factory or business may be difficult or impossible to discover. They do many repetitive and almost automatic tasks concerning which no memory exists. Yet their composite efforts make machines and records whose complexity, efficiency, and accuracy are beyond anything imaginable in 1886. In my view the anonymity of the recorder or the impossibility of tracing him create as valid a necessity as does his death for allowing his business record to be admitted.30

37 (1939), 17 Can. B. Rev. 469, 481-482.

38 Approved in 1953 by the U.S. National Conference of Commissioners on Uniform State Laws, and by the American Bar Association. Earlier, a committee established in 1927 under the auspices of the Commonwealth Fund had proposed the general adoption of the Massachusetts Statute extended so as to cover all written declarations with no limitation to those by deceased persons. In 1936 the Uniform Business Records Act was approved by the Commissioners on Uniform State Laws; its provisions are similar to those of the Uniform Rule. The Commonwealth Fund Act has been adopted by four states, the Uniform Business Records Act by the Federal Congress and 26 states, and the Uniform Rule by one state: Wigmore on Evidence, vol. V, s. 1520, (3rd ed. 1940, and 1954 supp.).

39 [1964] 3 W.L.R. 145, 173; [1964] 2 All E.R. 881, 898. Here it may be observed that, in the field of banking, the Parliaments and legislatures of England and Canada have recognised the need for reform as to regular business entries: see the Bankers' Books
Evidence Act, (Imp.) 42-43 Vict., c. 11; and in Canada, e.g., the Alberta Evidence Act.
R.S.A. 1955, c. 102, s. 41 (2), and the Trust Companies Act. (Alta.) 1960, c. 110, s. 60. Government records are treated similarly in the Alberta Evidence Act, s. 36 (i). In each instance copies of entries are prima facie proof of the "matters, transactions and accounts therein recorded": see Alberta Evidence Act. s. 36 (1). 
In the words of another commentator, Myers shows "how irrelevant our law of evidence is to contemporary realities." $\$ 0$ Fortunately, all members of the House of Lords seemed to be aware of this, so that even members of the majority urged statutory reform. Lord Reid said:

The only satisfactory solution is by legislation following on a wide survey of the whole field, and I think that such a survey is overdue. A policy of make do and mend is no longer adequate.41

It would seem to be a consequence of this call for legislative reform that on September 23rd, 1964, the Lord Chancellor and the Home Secretary announced that they had asked the Law Reform Committee and the Criminal Law Revision Committee to undertake a simultaneous review of the law of evidence. The terms of reference of both committees are as follows:

To review the law of evidence in civil/criminal cases and to consider whether any changes are desirable in the interests of the fair and efficient administration of justice; and in particular to consider what provision should be made for modifying rules which have ceased to be appropriate in modern conditions. ${ }^{42}$

*Addendum

\section{RECENT DEVELOPMENTS IN THE LAW OF CROWN PRIVILEGE}

The deference long paid to Duncan v. Cammell Laird \& Co. ${ }^{43}$ has been shattered in recent years in Canada and throughout the Commonwealth. No more is it accepted without question that the courts must regard as conclusive any claim to Crown privilege, even though it be properly framed.

Duncan v. Cammell Laird was a civil action brought against the builder of the submarine Thetis by the estates and dependents of certain of the hands lost when the submarine foundered during trials. The plaintiffs demanded production by the defendant of the plans of the ship, but privilege was claimed in an affidavit of the First Lord of the Admiralty, and the claim was upheld by the House of Lords. In the sole judgment delivered by Viscount Simon, L.C., the conclusiveness of the Crown's claim, and the inability of the courts to examine the documents

40 (1964, 27 Modern L. Rev. 606.

41 [1964] 3 W.L.R. 145, 156; [1964] 2 All E.R. 881, 886. And see Lord Morrls of Borth-y-Gest quoted ante, n. 26.

42 The Times (London), Sept. 24, 1964.

- Addendum.

Since the writing of this article, the U.K. Parliament has enacted the Criminal Evidence Act, 1965, which reverses Myers. v. D.P.P. in criminal proceedings. The Act provides that a document is admissible as evidence of a fact tended to be established by a statement in the document, if

(a) the document is, or forms part of, a record relating to any trade or business and and compiled, in the course of that trade or business, from information supplied (whether directly or indirectly) by persons who have, or may reasonably be supposed to have, personal knowledge of the matters dealt within the information they supply; and

(b) the person who supplied the information recorded in the statement in question is dead, or beyond the seas, or unfit by reason of his bodily or mental condition to attend as a witness, or cannot with reasonable diligence be Identifled or found, or cannot reasonably be expected (having regard to the time which has elapsed since he supplied the information and all the circumstances) to have any recollection of the matters dealt with in the information he supplied.

As Dr. Cross points out in (1965), 28 Modern L. Rev. 571, the result of this statute is that records such as those in the Myers' case, and a company's accounts, will now be that records such as those in the Myers case, and a company's accounts, will now be but praises its omission of certain features of the Evidence Act, 1938.

43 [1942] A.C. 624, [1942] I All E.R. 587 (H.L.). 
or in any way question the claim, were recognized in language of apparently general application.

For this view there was earlier authority in the lower courts, but there was also earlier authority for the contrary position. The latter body of cases included a decision of the Judicial Committee of the Privy Council in Robinson v. State of South Australia, ${ }^{44}$ where a ratio decidendi had been that the court does have the power to inspect the documents to decide whether the claim to privilege is to be recognized.

In cases after the Second World War there was general unease about applying Viscount Simon's remarks where the ground on which the privilege was claimed was far removed from the protection of the security of the State, and was rather the desirability of encouraging candour among civil servants. The case which most vividly illustrated the harm capable of being done to a private litigant by recognition of the Crown's claim to privilege on this ground was Ellis v. Home Office, ${ }^{45}$ in which the plaintiff, a prisoner, sued the Minister responsible for the prison in which he was detained for damages for personal injuries sustained at the hands of a fellow-prisoner. The plaintiff alleged that the prison authorities ought to have kept his co-prisoner under restraint, and that in not doing so they were negligent. The plaintiff demanded production by the defendant of reports made by the prison doctor and the prison hospital staff to the Home Office, and police reports as to what had happened. Privilege was claimed on the ground that production of those documents would be contrary to the public interest, and the Court of Appeal held that the claim to privilege must be recognized. However, two members of the court admonished the government that, when deciding whether or not to claim privilege, a Minister of the Crown ought to include the desirability of ensuring fairness in the administration of justice as one of the elements of the public interest to be considered in reaching his decision. Morris and Singleton, L.JJ., in passing these strictures, were merely giving advice; and they did not doubt that the Minister's decision, however reached, was conclusive.

The end result in Ellis v. Home Office was a denial of justice to the plaintiff. The remarks of their Lordships, and extrajudicial criticism, caused the Lord Chancellor to make a statement to the House of Lords on June 6th, 1956, in which he stated that as a matter of policy Ministers of the Crown would thenceforth not claim privilege for certain kinds of documents. ${ }^{40}$ These included reports of Government employees concerning motor vehicle and other accidents involving Government employees, medical records kept by Departments as to the health of civilian employees, and factual reports within the Government relevant in contractual actions against the Crown. This was, of course, only a statement of policy; and did not affect the legal rights of the Crown.

Meanwhile, the erosion of Duncan v. Cammell Laird had begun in the Canadian courts. In Regina v. Snider, ${ }^{47}$ four out of nine members of the Supreme Court of Canada, in a judgment delivered by Kellock, J., held

44 [1931] A.C. 704.

45 [1953] 2 Q.B. 135, [1953] 3 W.L.R. 105, [1953] 2 All E.R. 149.

$40197 \mathrm{H}$. L. Deb. 741, reproduced in Sir C. K. Allen's Law and Orders 468-473 (2nd Ed.). 47 [1954] S.C.R. 479; [1954] 4 D.L.R. 483. 
that Duncan's case did not apply to criminal proceedings. In a prosecution for conspiracy to keep a common betting house, the Crown in the right of the Province subpoenaed the Director of Taxation for the District of Vancouver, requiring him to give evidence and to produce the income tax returns of the accused. In an affidavit, the Minister of National Revenue objected to the production of the documents and to the giving of oral evidence on the ground that such production would be prejudicial to the public interest. Kellock, J., noted that in Duncan's case Viscount Simon, L.C., himself had said that "The judgment of the House in the present case is limited to civil actions, and the practice, as applied in criminal trials where an individual's life or liberty may be at stake, is not necessarily the same."4s

The judgment of Locke, J., also emphasised that Duncan v. Cammell Laird did not apply to criminal proceedings. ${ }^{40}$ That of Estey, J., expressly accepted Viscount Simon's "observations" as having "resolved the different opinions expressed by the authorities as to the right of a presiding judge to examine the documents" for which privilege is claimed. Estey, J., noted that in Duncan's case "the House of Lords expressly disapproved of the practice followed in Robinson v. State of South Australia ...., where the Judicial Committee 'remitted the case to the Supreme Court with the direction that it was one proper for the exercise of the Court's power of inspecting documents to determine whether their production would be prejudicial to the public welfare'."so

Cartwright, J., emphasised that Duncan v. Cammell Laird must be read in the light of the facts of that case, and also noted that the judgment of the House of Lords was limited to civil actions. However, Cartwright, J., went on to say that the Minister's objection could not be sustained, for the grounds upon which the objection was made "appear to me to be grounds of the sort which Viscount Simon indicated ... 'would not afford to the Minister adequate justification for objecting to production'."51 Yet, it is apparent that Viscount Simon did not regard the court as having any power to question the grounds on which privilege is claimed. The words quoted by Cartwright, J., were part of a passage intended to be merely admonitory. ${ }^{52}$ In any event, the judgment of Cartwright, J., while clearly refusing to recognise the objection to production as conclusive, does not define the approach to be adopted by the court.

Only Rand, J., ${ }^{33}$ developed and delineated an approach which repudiated Duncan's case altogether. Expressly relying on Robinson's case, Rand, J., upheld the right of the court to determine whether the documents for which privilege is claimed

might, on any rational view, either as to their contents or the fact of their existence, be such that the public interest requires that they should not be revealed; if they are capable of sustaining such an interest, and a minister of the Crown avers its existence, then the Courts must accept his decision. On the other hand, if the facts, as in the example before us, show that, in the ordinary case, no such interest can exist, then such a declaration of the Minister must be taken to have been made under a misapprehension and be disregarded. ${ }^{54}$

18 [1942] A.C. 624, 633-634.

t9 [1954] S.C.R. 479. His judgment was a simple endorsement of the judgment of the Chief Justice of British Columbia, which was based on the reason stated.

50 Ibid., at 494 .

31 Ibid., at 497.

52 See Reese v. The Queen, [1955] Ex. C.R. 187. 195.

os With whose judgment Rinfret, C. J., concurred.

st $\lceil 1954]$ S.C.R. 479, 485. 
As has been observed elsewhere, the test stated by Rand, J., is "roughly similar to that commonly exercised by courts of appeal over the findings of juries."

There have been three reported Canadian cases since Regina v. Snider. In Reese v. The Queen, ${ }^{56}$ Cameron, J., while upholding the Crown's claim to privilege, did so after subjecting the facts before him to the criterion enunciated by Rand, J. This was a civil action in which the petitioner alleged a contract by the Crown to convey to him the mineral rights to certain lands. He applied for an order directing the Crown to produce certain documents essential to his case-letters between the Commissioner of the Soldier Settlement Board and the Deputy Superintendent of Indian Affairs, written instructions given by the Board to a local official, written instructions given by the Deputy Minister of Veterans' Affairs to the Board, and a letter written by the Secretary to the Cabinet to the Department of Veterans' Affairs. Cameron, J., held that there was a "clearly discernible public interest in protecting from production correspondence and memoranda passing between members of one or more departments of government to the extent that the head of the department considers that they should not be disclosed." That interest lies in the desirability of encouraging "candour, completeness and freedom of expression." His Lordship thus echoed the words of Viscount Simon that "the candour and completeness of such communications might be prejudiced if they were ever liable to be disclosed in subsequent litigation."

The irony of Reese v. The Queen is that, although Cameron, J., applied Mr. Justice Rand's test, the result of his doing so was no different than the result of applying Duncan v. Cammell Laird in Ellis v. Home Office. If Canadian judges are prepared to apply $\mathrm{Mr}$. Justice Rand's approach, the effect of their doing so will be insignificant unless they are also prepared to hold that at least in some circumstances ordinary communications between civil servants are not "on any rational view ... capable of sustaining such an interest" as to justify the recognition of privilege from production.

In Miles v. Miles, ${ }^{58}$ Smily, J., in the High Court of Ontario, held that the decision in Regina v. Snider must be restricted to criminal proceedings. He cited an unreported British Columbia decision, Zorze v. Barker, apparently also decided since Snider, in which Macfarlane, J., had come to the same conclusion. In each case it was held that in civil procedings a properly framed claim to privilege is conclusive, Duncan v. Cammell Laird being applied.

In a Quebec case, In re Mercier, ${ }^{50}$ the Court of Appeal reversed a bankruptcy judge's decision to order production of documents for which

55 Willis (1955), 33 Can. B. Rev., 1186, 1187, In a note on Reese v. The Queen. His earller comment on 'Snider's case, in (1955), 33 Can. B. Rev. 352, had erroneousiy stated the effect of Mr. Justice Rand's judgment to be that if the grounds on which the privilege is claimed do not, in the opinion of the Court, show the existence of such an interest the Court will order production.

sc [1955] Ex. C.R. 187, [1955] 3 D.L.R. 691.

67 [1942] A.C. 624,635 .

58 (1960, 24 D.L.R. (2d) 228 . The form of the affidavit sworn by the Minister of National Revenue in the case is particularly complete.

59 [1964] B.R. 349. Taschereau, J., applied Duncan v. Cammell Laird. The other majority judge, Badeaux, J., distinquished Snider on the ground that it was a criminal case, and also held that in any event it was irrelevant because of the broad wording of the Civil Code article authorising a claim to privilege. 
the Attorney-General had claimed privilege. Again Duncan's case was applied, at least by one of the judges. It can scarcely be said that, so far, the Canadian lower courts have been adventurous in entering the doors opened by Rand and Cartwright, JJ.

In recent years elsewhere in the Commonwealth, the general applicability of Viscount Simon's remarks has been repudiated. In Glasgow Corporation v. Central Land Board, ${ }^{, 0}$ the House of Lords for Scotland held that the law of Scotland had developed independently and that the observations in Duncan's case, so far as they related to the law of Scotland, must be regarded as obiter dicta. All members of the House held that in Scotland the court has the power to override the objection of a Minister to produce documents on the ground that it would injure the public interest to do so. Lord Normand said that the power "must be used with the greatest caution and only in very special circumstances."61 However, while asserting the existence of this power, their Lordships declined to exercise it on the facts before them; although, in Lord Radcliffe's words,

Most of the documents in question appear to be departmental minutes, and they can hardly relate to anything but questions as to the proper principles and methods to be followed in assessing development charges. Nothing of high politics, diplomatic relations or State Secrets can be involved ... The Minister's certificate says no more than that he has formed the view that on grounds of public interest the documents ought not to be produced 'because they belong to a class which it is necessary for the proper functioning of the public service to withhold from production.'

Lord Radcliffe commented that "I should myself have supposed Crown servants to be made of sterner stuff."

Although Lord Radcliffe warned that in the future a Scottish judge might disregard the Crown's objection, he joined the other members of the House in holding that the Court below had not applied any wrong principle in exercising what was essentially a discretionary power.

In New Zealand, the Court of Appeal in Corbett v. Social Security Commission $^{63}$ refused to follow Duncan v. Cammell Laird and chose to apply the law of Scotland as stated in the Glasgow Corporation case. The plaintiff claimed a family benefit under the Social Security Act and asked for discovery of documents in the Crown's possession. The Minister objected to production of some twelve documents which he said he had personally examined, on the ground that they fell within "the class of documents which for the proper functioning of the public service it is necessary to keep confidential, not only because they are brought into existence for that purpose [whatever that means] but also to ensure freedom and candour of communication within the public service." The form of the affidavit was thus satisfactory, and was conclusive if Duncan v.Cammell Laird applied in New Zealand. The majority of the Court of Appeal held that it did not. ${ }^{64}$ However, instead of deciding that Robinson's case applied so as to permit the court to inquire whether a claim to privilege were justified and if necessary to inspect the documents in question, the court applied the law of Scotland, viz., that the court has

60 [1956] Sess, Cas. 1 (H.L.); [1956] S.L.T. 41.

$61[1956]$ Sess. Cas. 1, 16. And at p. 11 Viscount Simonds said that the power has been exercised "rarely, very rarely in recent times." 62 Id. at 19-20.

(i3 [1962] N.Z.L.R. 878

64 The reasons are summarised by Coote in [1962] Camb. L.J. 174. 
an inherent power to override a claim to privilege. In applying this power, the court held the case at bar not to be one of those "very rare" occasions (of which Viscount Simon had spoken) when the power should be exercised, and all members of the court concurred in refusing to order production.

The conflict between the House of Lords and the Privy Council was again considered in Bruce v. Waldron. ${ }^{\circ 5}$ This was a criminal prosecution for illegal betting. The Minister responsible for the Police Department objected by affidavit to the production of certain vouchers on the ground that production would be injurious to the public interest. However, the magistrate made an order the effect of which was to require the permanent head of the Police Department to attend and submit evidence to substantiate the objection. This order was challenged in the Supreme Court of Victoria, which followed Robinson v. South Australia, rather than Duncan v. Cammell Laird. As summarised by one commentator,

Their Honours pointed out that circumstances have changed considerably in England since 1942, that the Cammell Laird decision was made in a wartime case-and in a period when the Government had not yet become substantially involved in commercial and industrial enterprises. Further, that the rule had been adversely criticised as leading to possible abuses of power; it had not worked well in England; it had been necessary to modify it there in practice; that it was possible that the House of Lords had misunderstood the facts in Robinson's case. Finally, the Court referred to the facts that the rule had no application in Scotland, was apparently not being applied in Canada, and would not be followed in New Zealand unless the Privy Council directed the courts there to do so."0

The Supreme Court of Victoria therefore held that it was not only permissible for the magistrate to inquire into the objection taken by the Minister; but it was most desirable that he should decline to give effect to it without first testing it for himself, either by inspecting the documents or by considering further evidence in relation to them. ${ }^{67}$

In two cases in 1964, the English Court of Appeal has joined the chorus of those attacking Duncan v. Cammell Laird. The cases are Merricks v. Nott-Bower ${ }^{\text {ss }}$ and In re Grosvenor Hotel, London (No. 2) ${ }^{69}$ In each case the court consisted of Lord Denning, M.R., Harman, L.J., and Salmon, L.J. In neither case did Harman, L. J., express any opinion on the matter; but in the earlier case both Lord Denning and Salmon, L.J., characterised Viscount Simon's remarks in Duncan v. Cammell Laird as obiter in so far as he said that a Minister's certificate is absolutely conclusive as to a claim for privilege on the ground that the documents are of "a class of documents which it is necessary to keep secret for the proper functioning of the public service."7o Salmon, L.J., emphasised that "that case was decided in the darkest days of the war"; and, although he recognised that Viscount Simon's dictum was "concurred in by each member of the House and is necessarily of very great persuasive authority," his Lordship said that "it is not binding." Salmon, L.J., concluded by suggesting that the practice in England might be

6.) [1963] V.R. 3 (S.C. Vict.).

66 Maher (1963), 79 L.Q.R. 37, 39.

67 The case could have been decided on the ground that Duncan v. Cammell Laird does not apply to criminal cases, or on the ground that the Minister's affidavit was defective in form in that it did not say that he had seen the documents in question.

$68[1964] 2$ W.L.R. 702, [1964] 1 All E.R. 717 .

69 [1964] 3 W.L.R. 992, [1964] 3 All E.R. 354 (petition for leave to appeal dismissed by H.L. In [1964] 3 W.L.R. 1029).

70 Lord Denning, M.R., in $|1964| 2$ W.L.R. 702, 709; Salmon, L.J., at 714. 
brought into line with that in Scotland. ${ }^{71}$ (However, it was not necessary to go further into the question of conclusiveness, as all members of the court agreed that the Minister's certificate inadequately set out the ground on which privilege was claimed; more detail must be given than a mere repetition of Viscount Simon's formula.)

In the Grosvenor Hotel case, the question of the conclusiveness of a Minister's claim to privilege, properly claimed, was squarely faced by Lord Denning, M.R., and Salmon, L.J. These were proceedings under the Landlord and Tenant Act, 1954, in which the lessees of the Grosvenor Hotel in London applied for a new lease after the landlords (the British Railways Commission) had given notice that, upon the termination of the tenancy on December 31,1962, they would oppose a new tenancy on the ground that they intended to occupy the building for the purpose of a business to be carried on by them therein. Under the Act, the British Railways Board (which by the time of this application had succeeded the British Railways Commission) had to establish that, as at the date of the hearing, they intended to occupy the premises for a business to be carried on by them. Thus, the intentions of the Railways Board were of very great importance in the litigation. The lessees applied for an order requiring the Railways Board to produce certain documents, to the production of which the secretary of the Board had objected in his two affidavits of documents. Crown privilege was claimed for some of these documents; the secretary in his first affidavit said only that they "cannot be disclosed without injury to the public interest." In argument, the Attorney-General gave a more detailed reason why disclosure would be injurious to the public interest-viz., that it was necessary to secure freedom and candour of communication in this class of document (letters and memoranda within the government service and that of the Board). Both Ungoed-Thomas, J., to whom the application was made in the first instance, and the Court of Appeal held that production of the documents ought not to be ordered. Ungoed-Thomas, J., followed Duncan v. Cammell Laird and even defended the idea of leaving the decision whether discovery is against the public interest entirely with the executive. ${ }^{i 2}$ Harman, L.J., reserved his opinion on the question of whether the court has the power to inspect documents where the class of documents does "not appear to have political or strategic importance but for which privilege is claimed apparently in order to shroud the authors in anonymity on the vague pretext that candour will be impaired if secrecy is not observed." However, Harman, L.J., did observe that he seemed "to detect a desire in the official mind to push ever forward the frontiers of secrecy. This is a process which I regard with distaste." ${ }^{\prime 3}$

Lord Denning, M.R., and Salmon, L.J., amplified the views they had expressed in Merricks v. Nott-Bower. Lord Denning said:

... the law of England should be brought into line with that of Scotland in this matter, and with the rest of the Commonwealth. The objection of a Minister, even though taken in proper form, should not be conclusive. If the court should be of opinion that the objection is not taken in good faith, or that there are no reasonable grounds for thinking that the production of the documents would be injurious to the public interest, the court can override the objection and order production. It can, if it thinks fit, call for the documents and inspect them itself 
so as to see whether there are reasonable grounds for withholding them: ensuring, of course, that they are not disclosed to anyone else. It is rare indeed for the court to override the Minister's objection, but it has the ultimate power, in the interests of justice, to do so. After all, it is the judges who are the guardians of justice in this land: and if they are to fulfill their trust, they must be able to call upon the Minister to put forward his reasons so as to see if they outweigh the interests of justice. ${ }^{i 4}$

Salmon, L.J., said the court would treat "with the greatest respect" any affidavit or certificate in proper form in which privilege is claimed. If privilege is claimed on the ground that the production of a document might imperil the safety of the State or diplomatic relations, the court will treat the claim as conclusive. His Lordship appears to regard "communications at a very high level, e.g., cabinet minutes, minutes of discussions between heads of departments, dispatches from ambassadors abroad and the like" as in the same position. However, in regard to classes of documents covering communications at lower levels, while in most cases of doubt the Minister's objection would be accepted by the court, neverthless the court "ought to have the power to override the executive" in any case where the class of documents "is such that any right-minded man would say: 'It is ridiculous for Crown privilege to be claimed for such a class'."75 If any test is enunciated by Salmon, L.J., as to when the court will exercise its residual power, it is this: "where a wholly unreasonable claim is made for a class of documents."70

On the general question of whether the public service can function properly if commonplace communications between one civil servant and another are privileged from production, Salmon, L.J., pointed out that

industry seems to have got along very well without privilege for communications even at the highest level ... I do not believe that business people who have to make reports or write letters or minutes as part of their ordinary daily work write any less candidly and freely than civil servants do at present. It seems to me that it would be an injustice to civil servants to hold that they are so timid and supine that they would not write freely and candidly unless they know that what they wrote could in no circumstances whatsoever come to the light of day.it

On the facts of the case before them, Lord Denning, M.R., and Salmon, L.J., refused to order production because the documents in question came into existence due to a statutory obligation upon the Railways Commission to furnish information to the Minister ${ }^{78}$ Their Lordships implicitly considered that circumstance to constitute a reasonable ground, or at least not a wholly unreasonable ground, for claiming privilege.

In the Grosvenor Hotel case Lord Denning, M.R., and Salmon, L.J., cited the Canadian case of Regina v. Snider in support of their views. Lord Denning, referring to "the valuable judgments on the subject given in Canada in Reg. v. Snider (a criminal case)" and to the recent New Zealand and Australian cases discussed above, said: "All these countries prefer the principles stated by the Privy Council in Robinson's case to

74 Id. at 1015.

7s Id. at 1026-27. He cited Ellis v. Home Office as an example of such a case.

76 Id. at 1028

i7 Id. at 1027 .

78 In Wednesbury Corporation v. Ministry of Housing and Local Government, [1955] 1 W.L.R. 261, an Identically constituted Court of Appeal repeated the same view and the same actual result. The Court refused to order production of departmental briefs and instructions given to inspectors appointed to hold a local inquiry. The Court held that the interests of justice did not require the overruling of the Minister's claim of that the interests of justice did not require the overruling of the Minister's claim of
privilege. Lord Denning. M.R. at p. 272, quoted Lord Radcliffe in the Glasgow Corporation case, where he said that he "did not feel any clear conviction that the production of the documents sought for is in any real sense essential to the appellants' case." 
those stated by the House of Lords in Duncan's case."is Salmon, L.J., also said that, in Australia, Canada, and New Zealand, as in Scotland, the judge can override the Minister. ${ }^{\mathrm{B} 0}$ However, these are misstatements of the total effect of the judgments in Reg. v. Snider, and of the decision in Corbett v. Social Security Commission; although they may be accurate as to the decision in Bruce v. Waldron. ${ }^{81}$

Nevertheless, subject to the possibility of the Grosvenor Hotel case being overruled by the House of Lords at some time in the future, it appears that the law of England is the same as that of Scotland and New Zealand; while in Victoria Robinson's case is followed. Just what the law of Canada is in civil cases cannot be stated with certainty; but no doubt in future Canadian cases the recent developments elsewhere in the Commonwealth will make it more likely that the approach of Rand, J., will be adopted, especially in the light of the similarity of his view to that of Lord Denning, M.R., and Salmon, L.J. Whether even this approach will result in a Minister's objection being overruled only in "very rare cases" remains to be seen. No doubt departmental practice, both at the federal and provincial levels, will determine the frequency with which the question will come before the courts. ${ }^{82}$

\section{CONCLUSIONS}

Hearsay and crown privilege are not the only topics of the law of evidence which beg attention and, if necessary, reform in Canada. Other

70 [1964] 3 W.L.R. 992, 1015.

80 Id. at 1025.

81 In (1963), 79 L.Q.R. 153, 154, Professor A. L. Goodhart had misstated the effect of Reg. v. Snider as follows: "The Supreme Court of Canada . . has refused . . to follow the decision [in Duncan v. Cammell Laird]." And in (1964), 80 L.Q.R. 158, 159 Sir Carleton Allen misinterprets Maher's comment (ante, $n$. 65) as far as New Zealand is concerned; and falls into Professor Goodhart's trap as far as Canada is concerned. He says: "Mr. Maher reports that both in Australia and New Zealand the majority of judges have declared their allegiance to the Privy Councll and have therefore followed Robinson's declared their allegiance to the Privy Councll and have therefore followed Robinson's
case. . Professor Goodhart points out that the Simon dragnet doctrine has been rejected in Canada and the United States, and has never existed in Scotland .... The General Council of the Bar of England, in a Memorandum on Crown Privilege issued in February, 1956, (reproduced in Sir C. K. Allen's Law and Orders, 460 (2nd ed.) also had misrepresented the Snider case. The memorandum said that

the Supreme Court of Canada declined to be bound by the principles laid down in Duncan v. Cammell Laird, and Estey, J., seemed to exclude from the privilege all documents except those the disclosure of which would prejudice the safety of the State and public security .... Rand. J., (with whom Rinfret, C.J., concurred) and Cartwright. J., held that if the Minister states his grounds for declaring that nondisclosure is required by the public interest and those grounds do not, in the opinion of the Court. show the existence of such an interest, the Court will order production ....

In the writer's opinion everything just quoted is incorrect. The ratio of the Court as a whole is impossible to define. Estey, J., expressly accepted Duncan v. Cammell Laird: Mr. Justice Cartwright's judgment perhaps can be read as doing no more than limiting Duncan v. Cammell Laird to civil actions; and the alleged position of Rand, J., is based on a statement by Professor John Willis in (1955), 33 Can B. Rev. 352, 354-355, which Professor Willis himself later corrected in 33 Can. B. Rev. 1186, 1187.

82 Provincial Evidence Acts must be looked to in order to determine whether they have in any way altered the common law. Thus, the Alberta Evidence Act. R.S.A. 1955, C. 102 , s. 35, "entitles" a deputy head of a Department "or other officer" called as a withess to object to the production of a document in his personal possession "on the ground that it is privileged." The witness's objection may be taken "in the same manner and has the same effect" as if a minister of the Crown were personally present and made the objection. The words in italics (the writer's own) would seem to leave the common law unimpaired, whatever it may be. However, an amendment in 1960 added s. 35a (2), which prohibits a Provinclal Government employee from disclosing "ins. 35a (2), which prohibits a Provincial Government employee from disclosing certifies that in his opinion

(a) it is not in the public interest to disclose such information, or

(b) the information cannot be disclosed without prejudice to the interests of persons not concerned in the litigation."

This amendment would appear to give a Minister of the Crown a conclusive power to claim privilege. If so, the discussion in this article of what the common law is can be of no practical significance within the sphere of s. 35a. 
such topics are the rule in Hollington v. Hewthorn; ${ }^{83}$ prior consistent statements; ${ }^{84}$ prior inconsistent statements; ${ }^{85}$ vicarious admissions; ${ }^{86}$ section 12 of the Canada Evidence Act insofar as it applies to an accused witness; ${ }^{87}$ illegally obtained evidence; ${ }^{88}$ and the evidence of doctors, priests, and social workers as to confidential communications. ${ }^{80}$ The writer is not suggesting that codification of the major rules of evidence would remove the basic problems of applying rules to an infinite variety of situations, but surely a degree of statutory reform and restatement of some of these rules would be desirable. Serious study of the whole of the law of evidence has taken place in the United States for almost seventy years, and is now beginning in England. Let us in Canada not wait any longer.

83 [1943] K.B. 587, [1943] 2 All E.R. 35. See Cowen and Carter, Essays on the Law of Evidence 173 (1955), and Cross, Some Proposals for Reform in the Law of Evidence (1961), 24 Modern L. Rev. 32, 55-58.

84 See Cross (1961), 24 Modern L. Rev. 32, 43-45; also, Corke v. Corke, [1958] P. 93, 108-109; [1958] 1 All E.R. 224, 234, per Morris, L.J.

8: See Cross (1961), 24 Modern L. Rev. 32, 46-47.

86 Id. at 53-55.

87 See C. A. Wright (1940), 18 Can. B. Rev. 808; Murray, Evidence: a Fresh Approach (1959), 37 Can. B. Rev. 576, 591.

88 See Cowen and Carter, ante, n. 83, ch. 3; Franck (1955), 33 Can. B. Rev. 721; Williams, Evidence Obtained by Illegal Means, [1955] Crim. L. Rev. 339, 343.

89 As to psychiatrists, see the recent decision of Stewart, J., in Dembie v. Dembie, reported only in Kirkpatrick. Privileged Communications in the Correction Services (1964) 7 Crim. L. Q. 305, 317. As to social workers, see the recent cases of Re Kryschuk (1958), 25 W.W.R. (N.S.) 77, 14 D.L.R. (2d) 676; and Brysh v. Davidson (1964), 44 W.W.R. (N.S.) 654, 42 D.L.R.' (2d) 673 (Alta. Dist.'Ct.). 